\title{
Dynamical contribution of mean potential vorticity pseudo-observations derived from MetOp/GOME2 ozone data into short-range weather forecast during high precipitation events
}

\author{
Siham Sbii ${ }^{1,2}$, Mimoun Zazoui ${ }^{2}$, Noureddine Semane ${ }^{1}$ \\ ${ }^{1}$ Centre National de Recherches Météorologiques, Direction de la météorologie Nationale, Casablanca, Morocco \\ ${ }^{2}$ University of Hassan II Mohammedia, Faculty of sciences and techniques, Laboratory of condensed matter, \\ Renewable Energy, Mohammedia, Morocco \\ *Corresponding author E-mail: sihamsbii@gmail.com
}

Copyright $\odot 2015$ Siham Sbii et al. This is an open access article distributed under the Creative Commons Attribution License, which permits unrestricted use, distribution, and reproduction in any medium, provided the original work is properly cited.

\begin{abstract}
Satellites are uniquely capable of providing uniform data coverage globally. Motivated by such capability, this study builds on a previously described methodology that generates numerical weather prediction initial conditions from satellite total column ozone data. The methodology is based on two principal steps. Firstly, the studied linear regression between vertical (100hPa-500hPa) Mean Potential Vorticity (MPV) and MetOp/GOME2 total ozone data (O3) generates MPV pseudo-observations. Secondly, the 3D variational (3D-Var) assimilation method is designed to take into account MPV pseudo-observations in addition to conventional observations.

After a successful assimilation of MPV pseudo-observations using a 3D-Var approach within the Moroccan version of the ALADIN limited-area model, the present study aims to assess the dynamical behavior of the short-range forecast at upper levels during heavy precipitation events (HPEs). It is found that MPV assimilation offers the possibility to internally monitor the model upper-level dynamics in addition to the use of Water Vapor Satellite images.
\end{abstract}

Keywords: Atmospheric Dynamics; Data Assimilation; High Precipitation Events; Numerical Weather Prediction; Ozone.

\section{Introduction}

Even with the great progress made over the recent decades in the areas of numerical weather prediction (NWP), which is providing the operational meteorological centers with reliable forecasts, NWP ability to predict high-impact weather events remains sometimes limited because of the system's complexity and its extreme nature. It is the case when dealing with the North West of Morocco, the Iberian Peninsula and western Mediterranean. During autumn, those regions are often prone to heavy precipitation and devastating flash floods resulting from several factors. For example, Jansa et al. (2001) [1] have demonstrated that in most of the heavy precipitation events (HPEs) in Mediterranean regions (around 90\%) there is a cyclonic center in the vicinity, usually located so that its presence favors the creation or intensification of a feeding flow of Mediterranean air towards the area affected by heavy rain. Besides, generally over the African-European-Asian region, in southern mid-latitudes, the tropical moisture export contributes up to $60 \%$ to climatological precipitation [2]. The orography in those regions plays also a role in the creation and enhancement of the cyclogenesis [3]. The latter can result from complex interaction of upper-level synoptic flow and local topography. Also, upper-level fronts and tropopause folds can exist prior to the onset of surface cyclogenesis and they are considered by many studies as significant components of the deepening process. Hoskins et al (1985) [4] acknowledged the analysis of isentropic potential vorticity (PV) maps as a crucial diagnostic tool for tropopause folds. For instance, a decrease in tropopause height, which is induced by a cyclonic isentropic PV flow anomaly, displaces stratospheric air into the troposphere and an increase in its height, which is induced by an anticyclonic isentropic PV flow anomaly, 
displaces tropospheric air into the stratosphere [5]. As a consequence, of this "PV thinking", there has been enormously increased interest in using PV for diagnosing cyclogenesis, for research and operational forecasting purposes [6,7].

Based on this principle, our study focuses on the PV as a quantity representing both the dynamic and thermodynamic state of the atmosphere [8]. Its property allows its use as a tracer of upper-level dynamics [7]. In fact, upper-level disturbances can be originated from upper-level positive PV anomalies penetrating into the upper troposphere. Arbogast et al. 2000 [9] showed, that some explosive cyclone developments are entirely due to upper-level PV coherent structure. Indeed, upper level PV streamers reduce static stability and may favor upward motion and finally convection [10].

On another hand, many researches have explored the correlation between total ozone (O3) and PV structure because the variation in both those quantities are transport-dominated and have high values in the stratosphere and low values in the troposphere. Thus, a close link exists between total column ozone and weather phenomena of great interest such as baroclinic troughs. In this idea order, some studies suggested that many of the upper-tropospheric synoptic-scale wind perturbations may be recovered from the ozone data. For instance, Jang et. al (2003) [11] proposed a methodology for incorporating total column ozone data from the Total Ozone Mapping Spectrometer (TOMS) into the initial conditions of a mesoscale prediction model. This was based on the strong correlation between vertical mean potential vorticity (MPV) and TOMS ozone and resulted in an improved mesoscale prediction.

Based on the same principle, our methodology, as described in [12], is based on a new MPV operator introduced and tested in the 3D-Var assimilation framework of the operational version of ALADIN-Morocco. The MPV pseudoobservations are constructed from total column data observed by GOME2 instrument on-board of the satellite MetOp. The objective of this MPV assimilation framework is to assess the short-range forecasts of ALADIN at upper levels. This assessment is performed through the study of two unusual HPEs observed over the area from the North West of Morocco to the Iberian Peninsula and western Mediterranean.

The reminder of this article is as follows: section 2 is devoted to present the materials and methods used in this study, the ozone data, the formulation of MPV and the correlation between MPV and O3, are presented in this section together with a brief description of the experimental setup. Section 3 focuses on the details of the two case studies. Results are discussed in section 4 , and final conclusion is given in section 5.

\section{Materials and methods}

\subsection{Ozone data}

MetOp is a polar satellite with two instruments on board: the Global Ozone Monitoring Experiment 2 (GOME-2) that retrieves the Total Column Ozone (TCO) data from the backscattered solar ultraviolet-visible (UV-Vis) radiance, and the Infrared Atmospheric Sounding Interferometer (IASI) that uses the thermal infrared radiance to derive total data. To ensure the quality of the satellite TCO data, Anton et al. [13] have demonstrated that, GOME-2 data, when validated over Iberian Peninsula, showed an excellent agreement with respect to the ground-based TCO, leading to the excellent performance of the GOME-2 instrument for obtaining TCO data for all sky conditions, even with a slight underestimation while IASI instrument significantly overestimates the Brewer measurements. Throughout the study, the ozone data used, in each case study, correspond to the GOME-2 observed between 09h and 15h, which corresponds to the ALADIN-Morocco operational assimilation window.

\subsection{Mean potential vorticity formulation}

As described in [12], the proposed approach of assimilating MPV in a 3D-Var framework is based on a linear regression between observed ozone from MetOp/GOME2 and vertical integrated Ertel PV. The PV computation utilizes ALADIN (resolution 10km and 60 levels) dynamical fields based on the following formulation:

$$
\mathrm{PV}=-g \zeta_{a} \frac{\partial \theta}{\partial P}-g \frac{f P}{R}\left(\frac{P_{0}}{P}\right)^{R / C_{P}}\left[\left(\frac{\partial u}{\partial P}\right)^{2}+\left(\frac{\partial v}{\partial P}\right)^{2}\right]
$$

Where: $\mathrm{g}=$ the gravity [ms-2]

$\zeta \mathrm{a}=$ vertical component of the absolute vorticity [s-1]

$\mathrm{u}, \mathrm{v}=$ the horizontal wind components $[\mathrm{m} / \mathrm{s}]$

$\theta=$ the potential temperature $\left[{ }^{\circ} \mathrm{K}\right]$

$\mathrm{R}=$ gas constant $[\mathrm{J}$ mol-1K-1]

$\mathrm{P}=$ the pressure $[\mathrm{Pa}]$

$\mathrm{P}_{0}=$ a reference pressure $[\mathrm{Pa}]$

$\mathrm{C}_{\mathrm{P}}=$ specific heat at constant pressure $[\mathrm{J} /(\mathrm{kg} . \mathrm{K})]$

$\mathrm{f}=$ Coriolis parameter $[\mathrm{s}-1]$ 
Then the MPV is estimated, by an integration of the PV between the levels P1=500hPa ET P2=100hPa using the following expression:

$M P V=\frac{1}{\Delta P} \int_{P_{1}}^{P_{2}} P V \cdot d P$

\subsection{Correlation between MPV and $\mathrm{O3}$}

The linear regression model that links TCO and MPV is given by:

$$
M P V=\alpha * 10^{-2} * O_{3}-\beta
$$

Given the fact that (3) is found to be monthly dependent [12], the MPV pseudo-observations are computed using different equations depending on the studied events (29/11/2010 - 28/09/2012) as described in the following table.

Table 1: Linear regression terms per event and the associated correlation coefficients

\begin{tabular}{llll}
\hline Month & $\alpha$ & $\beta$ & Correlation Coefficient \\
\hline November 2010 & 0.3712 & 0.8448 & 0.8054 \\
September 2012 & 5.3146 & 13.445 & 0.8265 \\
\hline
\end{tabular}

\subsection{Experiment setup}

All simulations, presented in this paper are based on the operational Moroccan version of ALADIN, running on $10 \mathrm{~km}$ horizontal resolution and 60 vertical levels. ALADIN is a limited-area spectral model that uses lateral boundary conditions from the global model ARPEGE/IFS. The version used in this study has its own data assimilation system, based on a 3D-Var scheme with an incremental formulation.

The experiments are carried out from a guess made available at 12h00 UTC. It is a 6-hour forecast from the previous assimilation cycle as shown in Figure 1.

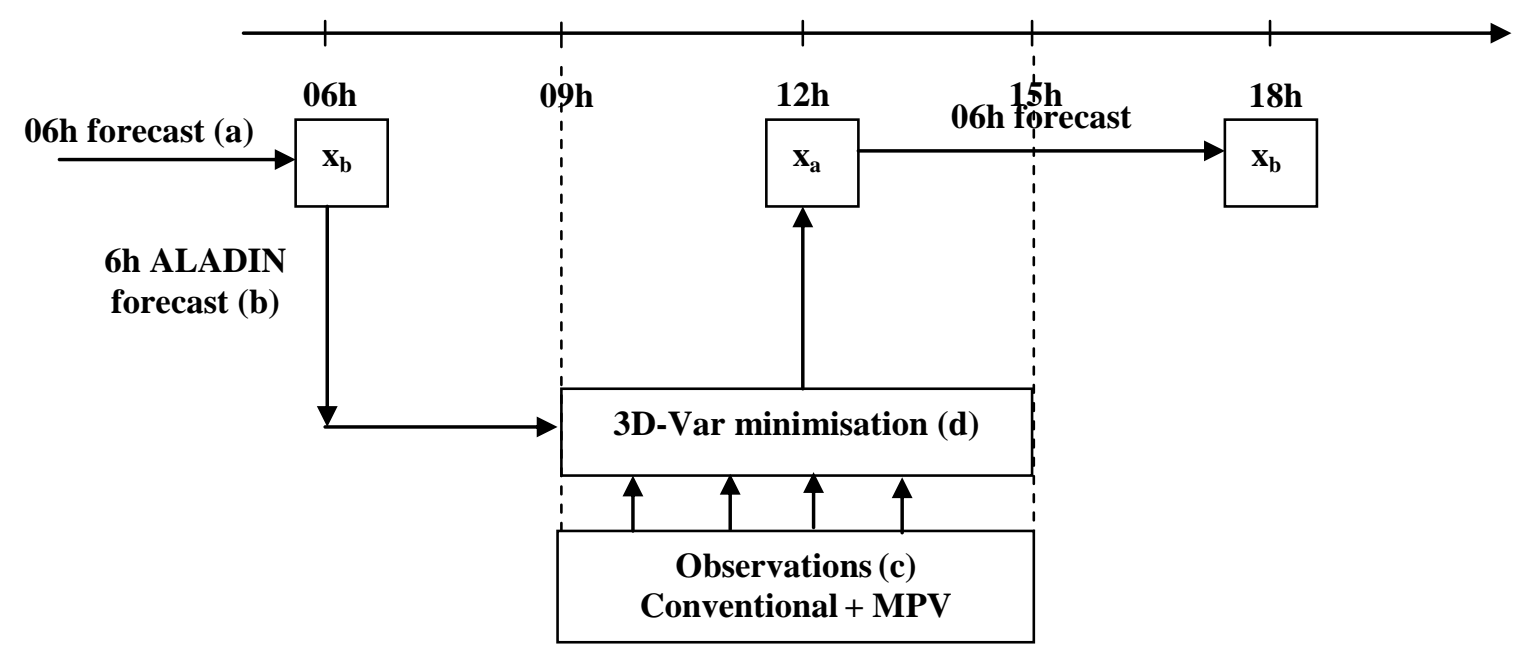

Fig. 1: Flow of 3D-Var procedure for the 12:00 UTC analysis time: (A) 6-h forecast from previous ALADIN Analysis is used as background Xb, (C) 6-h forecast from $\mathrm{x}_{\mathrm{b}}$, the analysis $\mathrm{x}_{\mathrm{b}}$ is performed at 12UTC by assimilating, over a 6-h assimilation window (09:00 UTC-15:00 UTC) (C), and after the 3D-Var minimization (D).

Figure 2 depicts the observation minus forecast over one-month when taking as observations brightness temperature from five channels of the Meteosat Second Generation satellite. This shows a bias varying from $-1^{\circ} \mathrm{C}$ to $1.5^{\circ} \mathrm{C}$. 


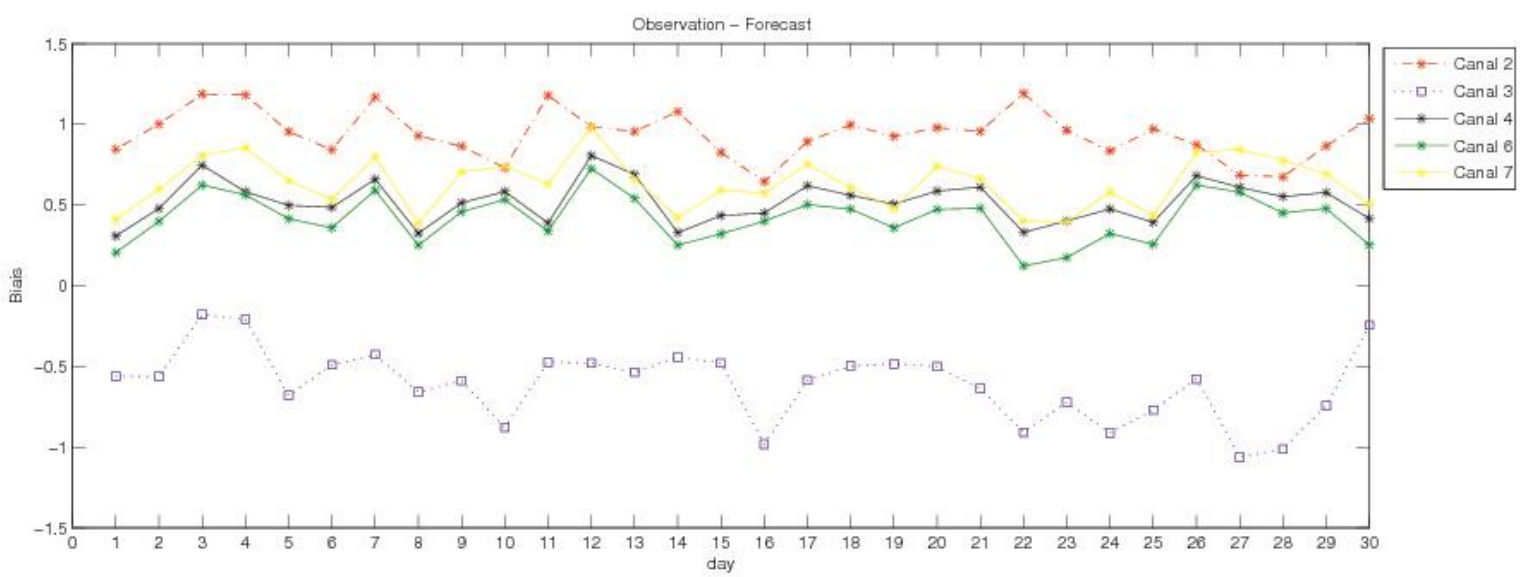

Fig. 2: Observation minus forecast over one-month when taking as observations brightness temperature from five channels of the Meteosat Second Generation satellite.

Using this framework together with the development of MPV operator, its associated tangent-linear and adjoint [12], we performed two experiments for each case study. The first (denoted hereafter CTL) has as initial condition a 3D-Var analysis of some conventional data, and the second (denoted hereafter NEW) incorporates MPV data in addition to those of the first experiment. After a quality control (selection of stations, levels and channels, flow-dependent background departure check, redundancy check, horizontal and vertical thinning of data denser than the model grid, etc.) and bias correction, the number of assimilated observations per event is listed in table 2, where SYNOP is covering land observations and ships, AIREP the Aircraft data, DRIBU the Drifting Buoys, TEMP the Radiosondes and MPV the pseudo-observations.

Table 2: The number of assimilated observations per event

\begin{tabular}{lll}
\hline Obstype & 1 st Event & 2nd Event \\
\hline SYNOP & 255 & 443 \\
AIREP & 555 & 756 \\
DRIBU & 9 & 40 \\
TEMP & 11 & 22 \\
MPV & 950 & 346 \\
\hline
\end{tabular}

\section{Case studies}

\subsection{The 29-30 November 2010 heavy precipitation event}

The first studied event corresponds to a period of a heavy and persistent rain from $29^{\text {th }}$ to $30^{\text {th }}$ November 2010 that brought severe flooding to Casablanca, the largest city in Morocco. Heavy rain and flooding also affected the North West region of the kingdom. Regarding to the Global Disaster Alert and Coordination System, this flood had severity class 2 corresponding to an extreme event with an estimated recurrence interval greater than 100 years. The main cause was torrential rain, which spawned floods that led to the drowning deaths of at least 34 people. Significant damage was reported to road infrastructure, causing the closure of several highways, national roads and regional traffic. Rail and air transport was also disrupted. That heavy rain resulted from gathering of cold air mass from the North and disturbances from the South associated with a jet-stream located exceptionally far more in the South. All that ingredients led to an exceptional situation.

Two quasi-stationary large upper troughs were located near on the Moroccan Atlantic few days before the $29^{\text {th }}$ of November 2010. Later, two more mobile and active short waves, that cut-off from the eastern through, merged with the second, and then it instigates the tropical moisture export. At the same time, the connection of a warm front from the South and cold front from the North generated an occlusion which was determined by the temperature contrast behind cold front and in front of warm front, this occlusion lengthened while the system weakened. The second upper air through provided the lifting that generated a southwest flux along the coast and then a warm advection associated with a conveyor belt of high wet-bulb potential temperature air ahead of a cold front. Also, the situation arrived west of Casablanca at exactly the right time and place to get the maximum benefits from its interaction with the dip in the jet stream exceptionally located more in the South. As a result, the upper air system became large enough to influence the system at the surface as well, and the two wrapped around each other into a single and deep one, extending from the upper levels. This added to the duration of the event as the circulation takes several hours.

Figure 3 displays the geopotential height (shaded) and temperature (dashed lines) at 500hPa together with mean sea level pressure (solid lines) on 29/11/2010 at 12UTC (left) and 18UTC (right) from ECMWF analysis. These latter 
analysis cover the period over which the model monitoring is performed, and gives an idea about how the systems evolve in time just before the occurrence of heavy rain.
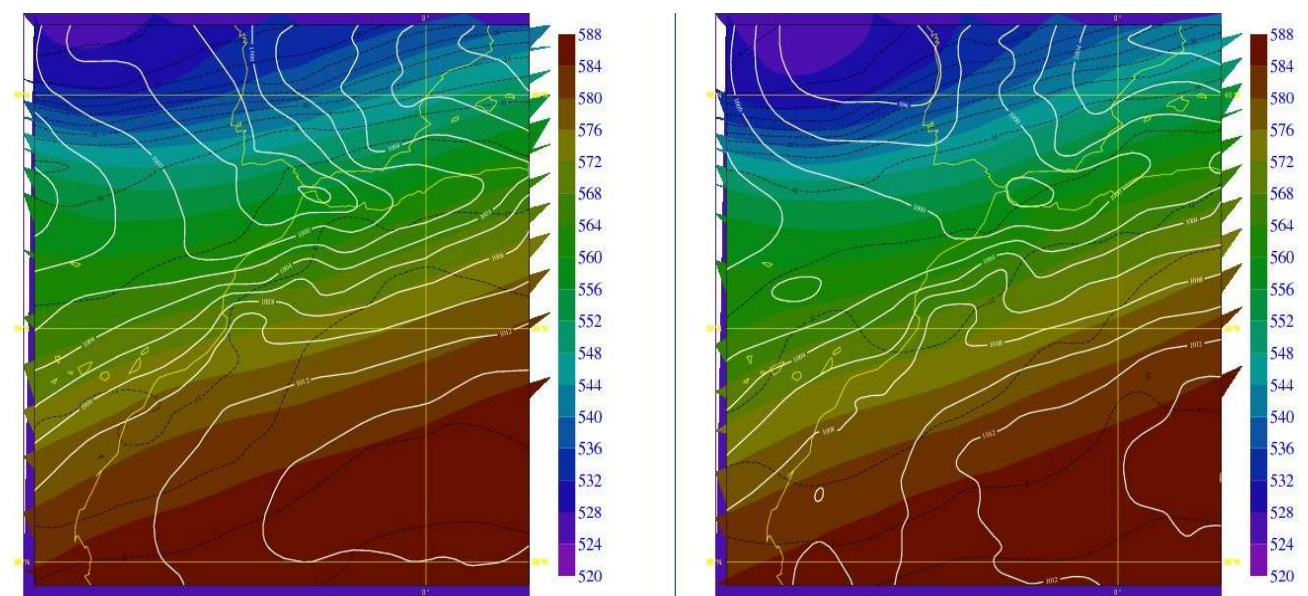

Fig. 3: Geopotential height (shaded) and temperature (dashed lines) at 500hpa together with mean sea level pressure (solid lines) on 29/11/2010 at 12UTC (left) and 18UTC (right) from ECMWF analysis.

The amounts of precipitation locally overpass $150 \mathrm{~mm}$ in 24 hours with a maximum of $177 \mathrm{~mm}$ in Casablanca (Fig. 4).

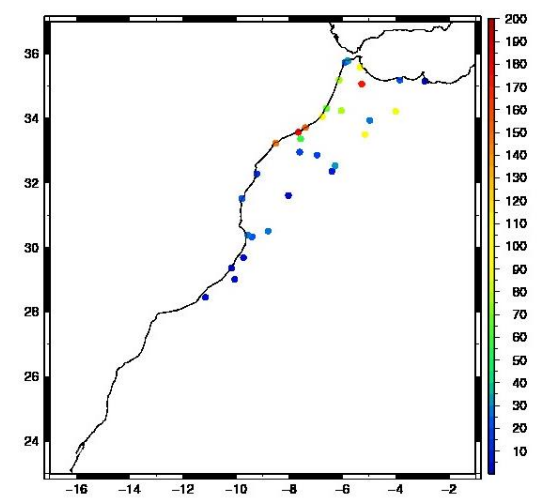

Fig. 4: $24 \mathrm{~h}$ rainfall amounts from the 20101129 at 06UTC

Figure 5 compares the rainfall amount of 29-30 November 2010 (blue) to that of the whole month of November 2010 (red) and that of the monthly normal over 30 years (green line). Interestingly, the month of November 2010 is extremely wet due to the pronounced contribution of the 29-30 November rainfall. In addition, returns from Casablanca Radar show a strong reflectivity around $18 \mathrm{UTC}$ of the $29^{\text {th }}$ November 2010 as indicated by figure 6 .

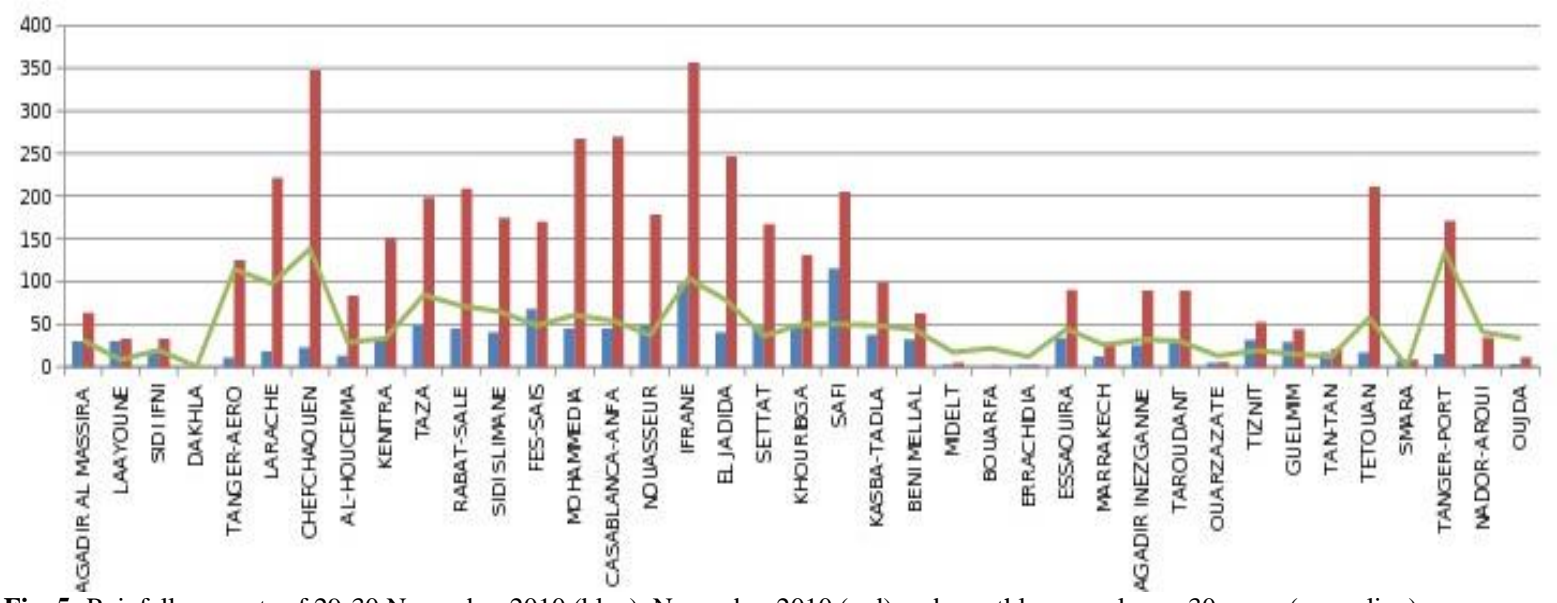

Fig. 5: Rainfall amounts of 29-30 November 2010 (blue), November 2010 (red) and monthly normal over 30 years (green line). 

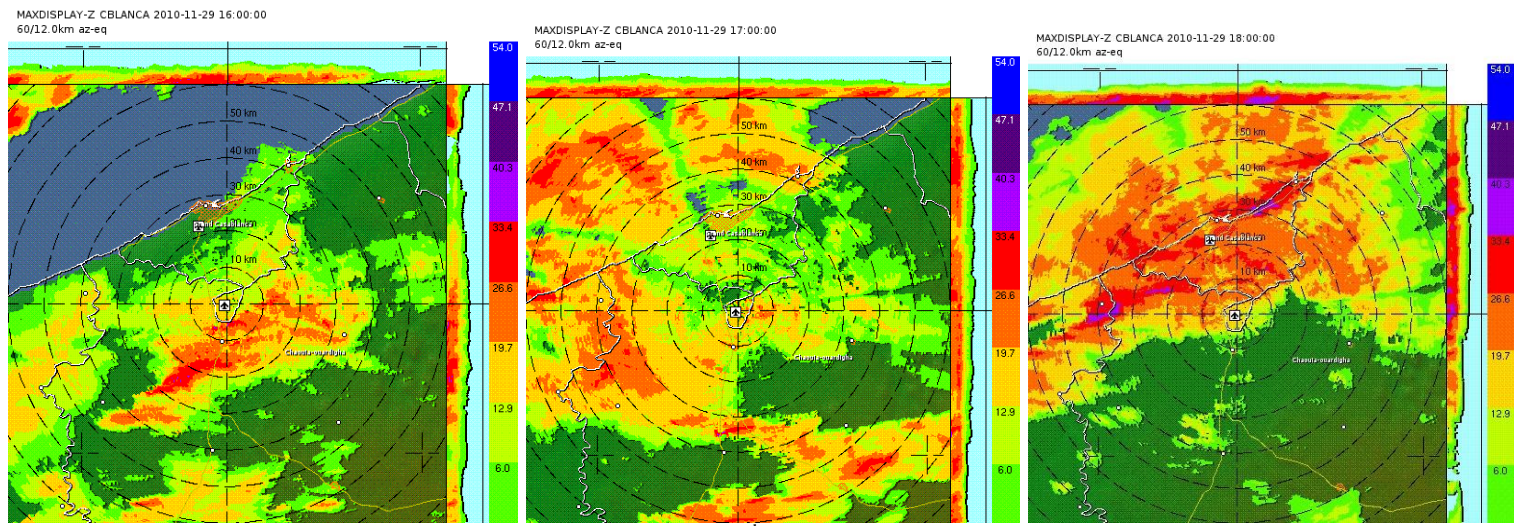

Fig. 6: Casablanca Radar returns (reflectivity in dBZ) observed on $29^{\text {th }}$ November 2010 at $16 \mathrm{UTC}$ (left), 17UTC (middle) and 18UTC (right).

Regarding the $\mathrm{O} 3$ distribution, a cell of high values, as depicted in figure 7, is localized over our region of interest. The total ozone values were exceeding 300DU in the Atlantic regions west of Iberian Peninsula. This cell, when compared to the corresponding monthly mean values, shows an ozone abundance of up to $30 \%$ over the Atlantic on the West of South Europe [http://lap.physics.auth.gr/ozonemaps2/].

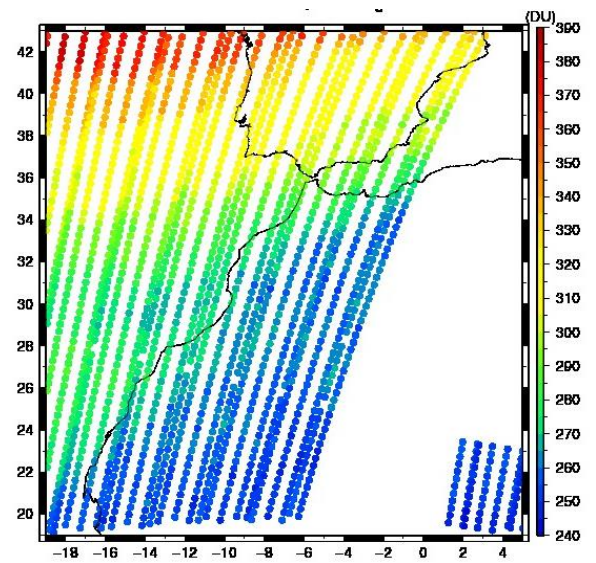

Fig. 7: GOME2 Total Column Ozone observed on the $29^{\text {th }}$ November 2010 between 09UTC and 15UTC

\subsection{The 28-29 September 2012 heavy precipitation event}

This second studied event corresponds to the Special Observation Period $n^{\circ} 1$ of the Hydro meteorological Experiment Program (Hymex) [14]. During this event, 13 casualties were registered over Spain, and thousands of people were evacuated, also rivers and watercourses were overflowed. Damage was also registered in cars, houses, bridges and roads. The event is characterized by a cut-off low, which was first centered on the South West of the Iberian Peninsula on $28^{\text {th }}$ September 2012 at 00UTC, then moved towards the North East. On $29^{\text {th }}$ September at 00UTC, it was centered in the Alboran Channel, just in the North of Morocco. And on $30^{\text {th }}$ September at 00UTC, it was located between the Balearics and the gulf of Lyon. In the North East flank of the cut-off low, were there was upward forcing, favoring the triggering of convection, low level depression and convergence ware created, reinforcing convection and heavy precipitation. The low-level convergence zone moved from inner Andalusia ( $28^{\text {th }}$ September at 06UTC) to Catalonia ( $29^{\text {th }}$ September at 12UTC), passing across Murcia and Valencia and the Balearics. Main convective systems were associated to the low-level convergence zone. As a result, torrential precipitation took place on 27, 28 and 29 September 2012.

At upper levels, a cut-off is centered over the southern tip of Portugal and tracks eastwards, driving a southerly and divergent flow over Spain with PV anomaly. At low levels, the meteorological situation is characterized by the presence of a convergence between north-easterly and easterly flows and low level jet. All these ingredients favor deep convection and heavy rain. The study of this HPE is used to monitor the ALADIN model ability in simulating the dynamics leading to cyclogenesis systems and then on precipitation.

Figure 8 displays the geopotential height (shaded) and temperature (dashed lines) at 500hPa together with mean sea level pressure (solid lines) on 28/09/2012 at 12UTC (left) and 18UTC (right) from ECMWF analysis. These latter analysis cover the period over which the model monitoring is performed, and gives an idea about how the systems evolve in time just before the occurrence of heavy rain. 

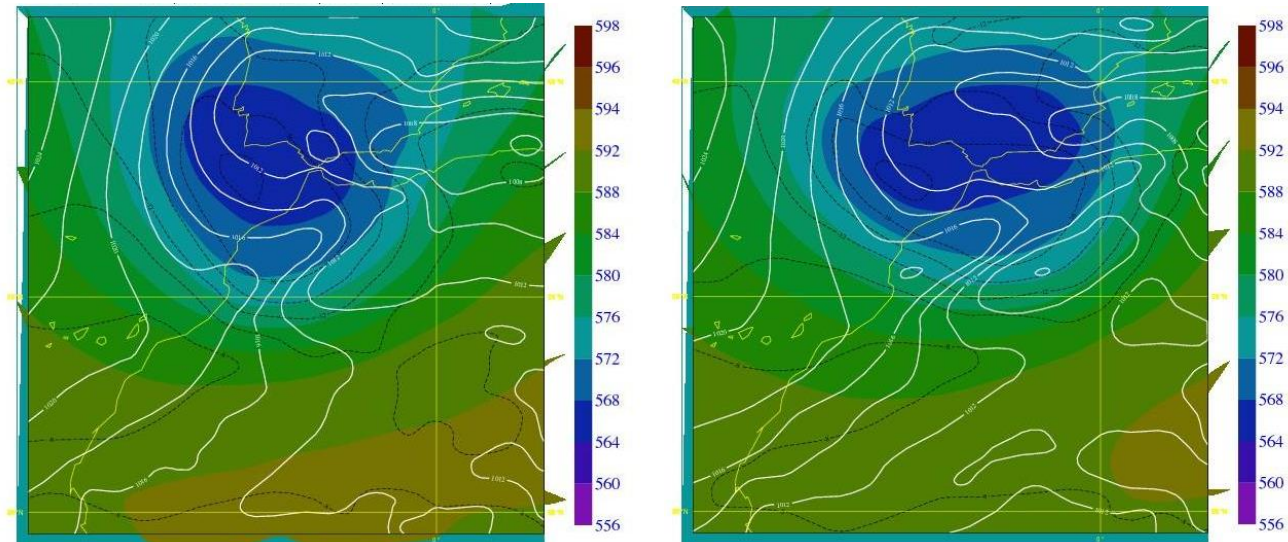

Fig. 8: Geopotential height (shaded) and temperature (dashed lines) at 500hpa together with mean sea level pressure (solid lines) on 28/09/2012 at 12UTC (left) and 18UTC (right) from ECMWF analysis.

In 24 hours, the amounts of precipitation locally overpass 200mm over Eastern Spain, while in Morocco, the Kenitra station registered more than $71 \mathrm{~mm}$ (Fig. 9). In addition, returns from Opera Radar show a strong reflectivity around $18 \mathrm{UTC}$ of the $28^{\text {th }}$ September 2012 as indicated by figure 10.

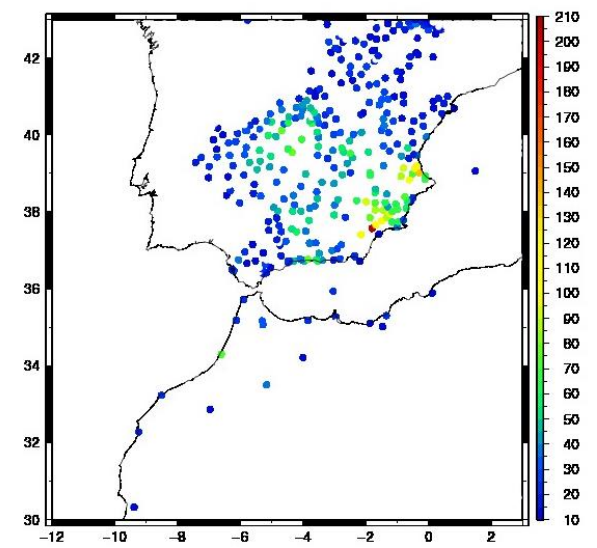

Fig. 9: $24 \mathrm{~h}$ rainfall amounts during the $28^{\text {th }}$ September 2012

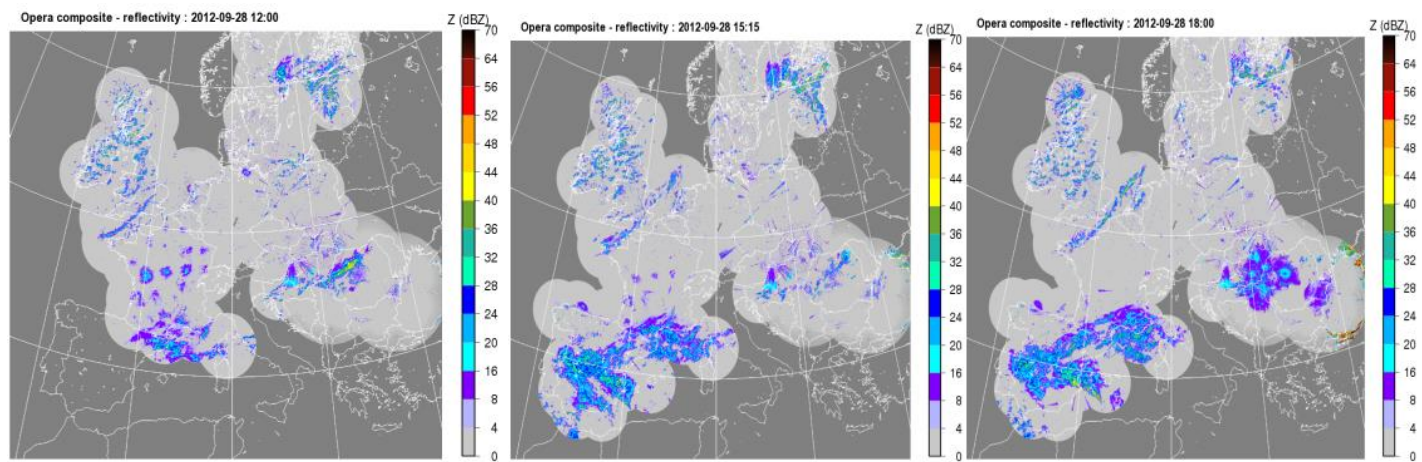

Fig. 10: Opera Radar returns (reflectivity in dBZ) observed on $28^{\text {th }}$ September 2012 at 15 hUTC (left), 17UTC (middle) and 18UTC (right).

Regarding the O3 distribution, a pronounced cell of high values exceeding 300DU, as depicted in Figure 11, is localized over Spain and the North West of the kingdom. 


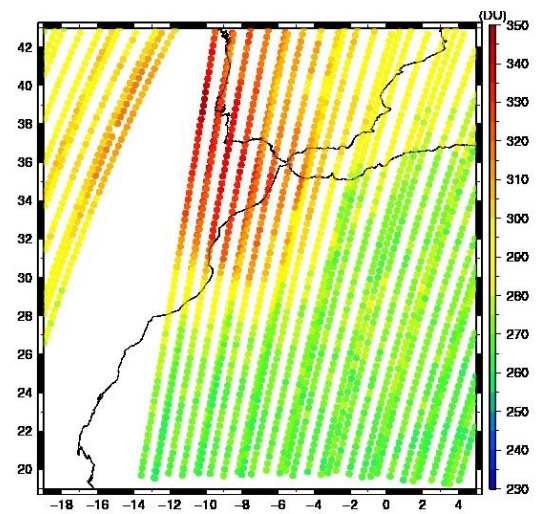

Fig. 11: GOME2 Total Column Ozone observed on the $28^{\text {th }}$ September 2012 between 09UTC and 15UTC.

\section{Main results}

\subsection{Analysis and free run comparison with independent observations}

In this section, the Meteosat Second generation (MSG) images are used as independent observations to detect the position of the PV anomaly. In fact, it is well known that a connection exists between PV structure, dry intrusions, dry bands, tropopause height and warm and dark area distribution on water vapor images. Furthermore, experience shows that water vapor (WV) channel images can serve operational forecasters as a valuable tool for monitoring upper-level dynamics. Indeed, forecasters detect failures in a model analysis by comparing the imagery information with NWP model output [15]. In particular, PV anomalies and areas of vertical motion that are involved in cyclogenesis are conspicuous as relatively warm features on the images, as shown by radiance temperature. This relationship can be explained using PV dynamics [16]. Moreover, Michel et al., 2005 [17] provided a diagnostic tool that works on real and model-generated satellite images, in order to highlight weaknesses in the analysis of cyclogenesis. It is an imageprocessing technique that first detects warm radiance features on WV imagery and then selects dynamic dry slots and intrusions that are related to cyclogenesis dynamics, in order to study the PV-WV relationship and to verify NWP forecasts.

Further to this approach and in order to highlight the added-value of PV-Ozone link in monitoring NWP analysis and short-range forecasts, the geopotential height on the tropoause level (1. 5PVU) from CTL and NEW are superposed on the Water Vapor image (6.2 $\mu \mathrm{m}$ channel) from the MSG (Fig. 12).

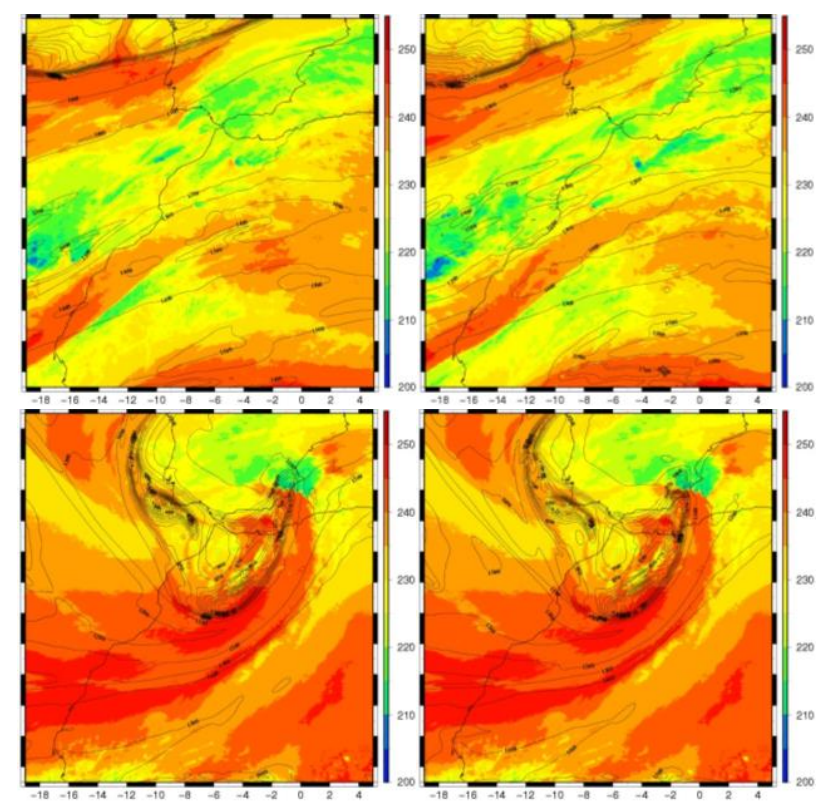

Fig. 12: 3 -h forecasted of geopotential height (lines) on 1.5PVU superimposed on MSG brightness temperature ( ${ }^{\circ} \mathrm{K}$ ) in WV Chanel $6.2 \mu \mathrm{m}$ (shaded) The left panel corresponds to CTL experiments, and the right one corresponds to NEW experiments. The upper panels are related to the $29^{\text {th }}$ November 2010 event, and the lower ones are related to the $28^{\text {th }}$ September 2012. 
On one hand, as expected, the CTL experiments show an excellent agreement between the PV anomaly localization and warm areas in WV distribution. On the other hand, the NEW experiments reproduce this agreement with a slight improvement in localization.

In term of monitoring vertical and time distribution of PV anomalies, figure 13 displays cross-sections of relative humidity together with PV along the axis of the anomaly displacement. This result confirms the agreement between CTL and NEW in terms of space-time evolution.
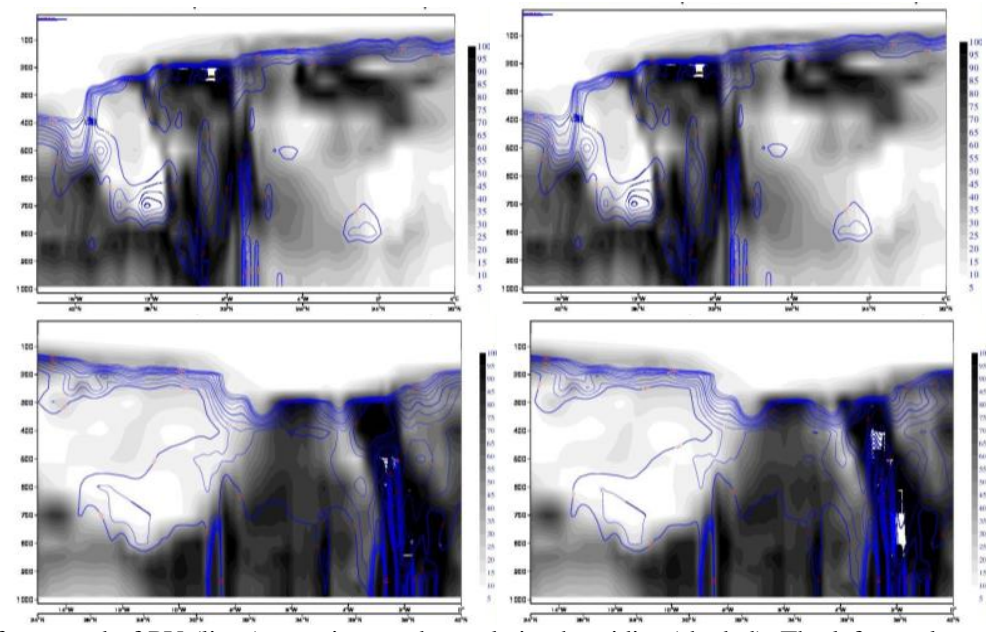

Fig 13: : Cross-section of 3-h forecasted of PV (lines) superimposed on relative humidity (shaded). The left panel corresponds to CTL experiments, and the right one corresponds to NEW experiments. The upper panels are related to the $29^{\text {th }}$ November 2010 event and the lower ones are related to the $28^{\text {th }}$ September 2012 .

Therefore, the comparison exercise between CTL and NEW experiments provided an additional monitoring tool of upper-level dynamics.

\section{Conclusion}

Mediterranean and North Atlantic regions are regularly affected by high-precipitating events that often lead to devastating flash floods. Forecasting such extreme events is still a challenge for operational Numerical Weather Prediction Systems. To address this issue, we have analyzed the possible added-value to the operational systems when MPV and O3 link is taken into account and integrated into initial conditions. Indeed, after a successful assimilation of MPV pseudo-observations using a 3D-Var approach within the Moroccan version of the ALADIN limited-area model, the present study evaluates the dynamical behavior of the short-range forecast at upper levels. More precisely, MPV assimilation constitutes a valuable tool to internally monitor upper-level dynamics in addition to the traditional use of Water Vapor Satellite images.

\section{Acknowledgement}

We are grateful to Dr. Yann Michel, Dr. Philippe Arbogast, Dr. Peter Knipetrz for offering advice in the beginning of this work, and to our colleague Khalid El Rhaz for his help in the meteorological analysis of extreme situations observed over Morocco. The author acknowledge Meteo-France and the HyMeX program for supplying the data, sponsored by Grants MISTRALS/HyMeX and ANR-11-BS56-0005 IODA-MED project.

\section{References}

[1] Jansa, A., Genoves, A., Picornell, M. A., Campins, J., Riosalido, R. and Carretero, O., "Western Mediterranean cyclones and heavy rain. Part 2: Statistical approach", Meteorological Applications, Vol. 8, (2001), 43-56. http://dx.doi.org/10.1017/S1350482701001049.

[2] Knippertz,P. and Wernli, H., "A Lagrangian Climatology of Tropical Moisture Exports to the Northern Hemispheric Extratropics", Journal of Climate, Vol. 23, (2010), 987-100. http://dx.doi.org/10.1175/2009JCLI3333.1.

[3] Horvath, K., Fita, L., Romero, R. and Ivancan-picek, B., "A numerical study of the first phase of a deep Mediterranean cyclogenesis in the lee of the Atlas Mountains", Meteorologische Zeitschrift, Vol. 15, No. 2 (2006), 133-146. http://dx.doi.org/10.1127/0941-2948/2006/0113.

[4] Hoskins, B. J., McIntyre, M. E. and Robertson, A. W., "On the use and significance of isentropic potential vorticity maps", Q. J. R. Meteorol. Soc., 111 (1985), 877-946. http://dx.doi.org/10.1002/qj.49711147002.

[5] Semane, N., Peuch, V.H. Bencherif, H. Massart, S., Cariolle, D., Attie, J.L. and Adiba, R. "An observed and analysed stratospheric ozone intrusion over the high canadian arctic UTLS region during the summer of 2003", Q. J. R. Meteorol. Soc., Vol. 133, (2007), 171-178. http://dx.doi.org/10.1002/qj.141.

[6] Santurette, P., Georgiev, CH. G., "Weather analysis and forecasting: Applying satellite water vapor imagery and potential vorticity analysis", Academic Press, 2005, 179p. 
[7] Hoskins, B.J, "Apotential vorticity view of synoptic development", Meteorological Applications, Vol. 4, 1997, 325-334. http://dx.doi.org/10.1017/S1350482797000716.

[8] Arbogast, P., "L'inversion du tourbillon potential", La Météorologie, Vol. 38, (2002).

[9] Chaigne, E. and Arbogast, P. "Multiple potential vorticity inversions in two FASTEX cyclones.” Q. J. R. Meteorol. Soc., Vol 126, (2000), 1711-1734. http://dx.doi.org/10.1002/qj.49712656608.

[10] Massacand, A.C., Wernli, H. and Davies, H.C. "Heavy precipitation on the alpine southside: An upper-level precursor", Geophysical Research Letters 25, (1998). http://dx.doi.org/10.1029/98GL50869.

[11] Jang, Kun-Il, Zou, X., De Pondeca, M. S. F. V., Shapiro, M., Davis, C., Krueger, A., "Incorporating TOMS zone Measurements into the Prediction of the Washington, D.C., Winter Storm during 24-25 January 2000", J. Appl. Meteor., 42, (2003), 797-812. http://dx.doi.org/10.1175/1520-0450(2003)042<0797:ITOMIT>2.0.CO;2.

[12] Sbii, S. Zazoui, M., Semane, N., Michel, Y. and Arbogast, P., "Exploring the Potential Application of MetOp/GOME2 Ozone Data to Weather Analysis", International Journal of Computer Science Issue, Vol. 10 (2013), Issue 2, No 3, 260-263.

[13] Antón, M., Loyola, D.,Clerbaux, C., López, M., Vilaplana, J.M., Ba-ón, M., Hadji-Lazaro, J., Valks; P., Hao; N.; Zimmer, W., Coheur, P.F., Hurtmans, D., Alados-Arboledas, L. "Validation of the MetOp-A total ozone data from GOME-2 and IASI using reference ground-based measurements at the Iberian Peninsula", Remote Sensing of Environment 115 (2011),1380-1386. http://dx.doi.org/10.1016/j.rse.2011.01.018.

[14] Ducrocq,V., Braud, I., Davolio, S., Ferretti, R., Flamant, C., Jansa, A., Kalthoff, N. Richard, E.,Taupier-Letage, I, Ayral, A.P, Belamari, S., Berne, A., Borga, M., Boudevillain, B., Bock,O., Boichard, J.L., Bouin, M.N., Bousquet, O., Bouvier, C., Chiggiato, J., Cimini, D., Corsmeier, U., Coppola, L., Cocquerez, P., Defer, E., Delanoe, J., DiGirolamo, P., Doerenbecher, A., Drobinski, P., Dufournet, Y., Fourrié N., Gourley, J.J., Labatut, L., Lambert, D., Le Coz, J., Marzano, F.S., Molinié, G., Montani, A., Nord, G., Nuret, M., Ramage, K., Rison, W., Roussot, O., Said, F., Schwarzenboeck, A., Testor, P., Baelen, J.Van, Vincendon, B., Aran, M., and Tamayo, J., "Hymex-sop1: the field campaign dedicated to heavy precipitation and flash flooding in the northwestern Mediterranean", Bull. Amer. Meteor. Soc., 95 (2014), $1083-1100$. http://dx.doi.org/10.1175/BAMS-D-12-00244.1.

[15] Georgiev, C. and Martin, F. "Use of potential vorticity fields, METEOSAT water vapour imagery and pseudo water vapour images for evaluating numerical model behavior", Meteorol. Appl., 8, 57-69. http://dx.doi.org/10.1017/S1350482701001050.

[16] Georgiev, C. "Quantitative relationship between METEOSAT water vapour data and positive vorticity anomalies: a case study over the Mediterranean". Meteorol. Appl., 6 (1999), pp. 97-109. http://dx.doi.org/10.1017/S1350482799001024.

[17] Michel, Y., Boutier, F., "Automated tracking of dry intrusions on satellite water vapour imagery and model output", Q. J. R. Meteorol. Soc. 132, (2006), pp. 2257-2276. http://dx.doi.org/10.1256/qj.05.179. 